\title{
SALMOND AND CORPORATE THEORY
}

\author{
Professor John H Farrar*
}

\begin{abstract}
Salmond's corporate theory was strongly influenced by Maitland and the German jurists of the late Nineteenth century. He did not receive their views uncritically and formulated his own theories in a pragmatic manner. His views on corporate theory and the State have been influential. As a judge he applied orthodox principles and made a useful analysis of the corporate constitution as it then existed.
\end{abstract}

Sir John Salmond is justly famous for his work on torts ${ }^{1}$ and jurisprudence ${ }^{2}$ and as a judge of the Supreme Court of New Zealand. What is less well known is that he had very distinct views on corporate theory which he developed in his Jurisprudence and also in some of the cases which he decided as a judge. ${ }^{3}$ His views were strongly influenced not only by the positivism and utilitarianism of Bentham and Austin but also by Maitland and the German jurists of the late $19^{\text {th }}$ century. ${ }^{4}$ At the same time he had a sharp and original mind which was capable of independent thought of a liberal and pragmatic nature. Looking back on it, a lot of the views that we now take as axiomatic in company law perhaps owe something to the clarity of his treatment of theory. His book on jurisprudence was popular until the 1970s and was treated as a useful theoretical foundation for the practice of law. ${ }^{5}$ Some of his views foreshadow the theories of Weber and Teubner and the modern attribution doctrine.

* Dean of Law, University of Waikato; Professorial Fellow, University of Melbourne.

1 Sir John Salmond The Law of Torts (6 ed, Sweet \& Maxwell, London, 1924).

2 Sir John Salmond Jurisprudence (2 ed, Sweet \& Maxwell, London, 1893). Salmond died in 1924. See Alex Frame Salmond - Southern Jurist (Victoria University Press, Wellington, 1995).

3 See Frame, ibid, 68-71. Compare the biased remarks of Harold Laski in M De Wolfe Howe (ed) HolmesLaski Letters 1916-1935 (Oxford University Press, Oxford, 1955) vol 1, 691-2.

4 See Salmond Jurisprudence, above n 2, 342 (footnote h).

5 See Sir Frederick Pollock's favourable review of the first edition in (1902) 18 LQR 431. However, he had a few criticisms - "We are rather sorry that he has not taken the 'realistic' theory of corporations more seriously: its failure to explain that peculiarly English monster the corporation sole is really no failure at all" (432). Maitland also thought well of the book. See Frame, above n 2, 71. Sir Alexander Turner once told me how he had been strongly influenced by this work early in his University studies and thought that it provided an excellent foundation for the practice of law. 
In this paper I will deal first with his views on corporate theory including the State and then examine the cases in which he was involved as judge which had a corporate element.

\section{SALMOND'S VIEWS ON CORPORATE THEORY}

Salmond's views on corporate theory appear in Chapter XV of his Jurisprudence, which deals with Persons. Salmond's basic view was that "persons are the substances of which rights and duties are the attributes. It is only in this respect that persons possess juridical significance, and this is the exclusive point of view from which personality received legal recognition". ${ }^{6}$ He distinguished between natural and legal persons and said that legal persons are beings, real or imaginary, to whom the law attributes personality by way of fiction when there is none in fact. Although Salmond adopted the fiction theory he did so with certain reservations. He said that, although fictitious personality involves personification, the converse is not true. ${ }^{7}$ Personification in itself is a mere metaphor, not a legal fiction. "Legal personality is a definite legal conception; personification as such is a mere artifice of speech designed for compendious expression". ${ }^{8}$ People talk about a bench of judges or a partnership as a firm. This is simply metaphorical usage.

A corporation is, on the other hand, a fictitious person representing a group of persons but is not identical with them. It is treated in law as a separate person. He followed the conventional distinction between corporations sole and aggregate. ${ }^{9}$ He thought that the chief difficulty in comprehending the true nature of a corporation sole is that it bears the same name as a natural person who is himself the sole member for the time being. ${ }^{10}$

He acknowledged that while he accepted the generally received view that corporations are fictitious persons the theory has not gone unchallenged. ${ }^{11}$ He referred to the views of Gierke ${ }^{12}$ that

6 Salmond Jurisprudence, above n 2, 329.

7 Ibid, 337. For a useful summary of the fiction theory and other theories see P Round Jurisprudence (West Publishing Co, St Paul, Minn, 1959) vol IV, 226-240.

8 Salmond Jurisprudence, above n 2.

9 Ibid, 339.

10 Ibid, 341.

11 Ibid, 342. See generally Alex Frame "Fictions in the Thought of Sir John Salmond" (1990) 30 VUWLR 159, 170 and following. This article contains a useful discussion of the role of fictions in legal and scientific thought.

12 Otto Von Gierke Die Genossenschaftstheorie (1887). The most relevant part of this was translated with an introduction by FW Maitland and published as Political Theories of the Middle Age (Cambridge University Press, 1900, reprinted 1958). For criticism of Von Gierke see F Hollis Corporate Personality. A Study in Jurisprudence (Oxford University Press, London, 1930) Part III - I The Theory of the Reality of Corporate Persons: Otto von Gierke - "he confuses the juristic interpretation of social facts with their intrinsic social character" (164). For cogent modern criticisms of Von Gierke's views see Gunter Teubner "Enterprise Corporatism: New Industrial Policy and the 'Essence' of the Legal Person" in Sally Wheeler (ed) A Reader 
the real Verbandspersonlichkeit is a group organism whose parts are human beings. He seemed to be aware of the problems of what Teubner has called "organicist collectivism". ${ }^{13}$ He drew attention to the fact that such a theory cannot accommodate the corporation sole and even in the case of a corporation aggregate "it seems impossible to admit that their personality is anything more than the outcome of metaphor and fiction". ${ }^{14}$ He then, in a memorable phrase, said, "The so-called will of a company is in reality nothing but the wills of a majority of its directors or shareholders. Ten men do not become in fact one person, because they associate themselves together for one end, any more than two horses become one animal when they draw the same cart". ${ }^{15}$ He thought that the apparent absurdity of treating a joint stock company as a mere fiction proceeded not from the fiction theory but from a misunderstanding of it. He said: "No-one denies the reality of the company in the sense of a group of shareholders. What is denied is the reality of its personality. A group or society of men is a very real thing, but it is only a fictitious person." 16 This passage appeared in the first edition in 1902. In the works cited in the 1924 edition, which include Gierke, Maitland, Pollock, Brown and Savigny, he also includes Gray. ${ }^{17}$ Brown and Gray were not cited in the first edition in 1902. In The Nature and Sources of the Law ${ }^{18}$ John Chapman Gray stated, "It should be observed that even if a corporation be a real thing, it is yet a fictitious person for it has no real will, but it would be a fictitious person only as an idiot or a ship is a fictitious person". ${ }^{19}$ Gray had referred to Gierke's views with some degree of scepticism. Gray argued, "Is the corporation to which these wills of individual men are attributed a real thing or only a thing of fiction, a fictitious entity? If it is a fictitious entity we have a double fiction; first a fiction on the creating of an entity, and then by a second fiction we attribute to it the wills of individual men. If the corporation is a real entity then we have need only of this second fiction." ${ }^{20}$ Having posed the problem he declined to solve it as he

on the Law of the Business Enterprise (Oxford University Press, Oxford 1994) 51. See also SJ Stoljar Groups and Entities: An Inquiry into Corporate Theory (ANU Press, Canberra, 1973) 183 and following.

13 Teubner ibid, 54. Teubner sees the substratum "as an autonomous communicative process with actual people simply being treated as part of this process's environment".

14 Salmond, Jurisprudence, above n 2, 350.

15 Ibid, 350 .

16 Ibid, 350-1. Compare C T Carr The General Principles of the Law and Corporations (being the Yorke Prize Essay for the Year 1902) (Cambridge University Press, Cambridge 1905) 185. "To impute a fictitious nature to a group-person is not to deny the reality of the members of the group."

17 Ibid footnote (h). For Maitland's views see also H D Hazeltine, G Lapsey and P H Winfield (eds) Maitland Selected Essays (Cambridge University Press, Cambridge, 1936).

18 John Chapman Gray The Nature and Sources of the Law Roland Gray (ed) (2 ed, The Macmillan Co, New York, 1927).

19 Ibid, 53.

20 Ibid, 52. 
feared he should "find no end in wandering mazes lost." ${ }^{21}$ It seems clear, therefore, that Gray derived some of these ideas from Salmond although he does not cite him. Salmond, however, wrote with greater lucidity.

Salmond thought that although corporations are fictitious persons the acts, interests, rights and liabilities attributed to them by the law are those of natural persons. ${ }^{22}$ Otherwise the law of corporations would be destitute of any relation to actual fact. His attribution doctrine seems to have preceded that of Lord Hoffmann delivering the judgment of the Judicial Committee of the Privy Council in Meridian Global Funds Asia Ltd v Securities Commission. ${ }^{23}$ Lord Hoffmann develops the attribution doctrine without reference to Salmond or indeed to counsel's argument and analyses it substantially in terms of systems of rules. A corporation is a bundle of rules interfacing with other bundles of rules. I am not sure that Salmond would have been happy with the latter analysis as he was ultimately rooted in the real world. Salmond the jurist would probably have been interested in Teubner's views that law is a second order autopoietic system ${ }^{24}$ and the corporation and corporate groups are further subordinate systems. ${ }^{25}$ The regulations of corporate constitutions are allowed by the State or sovereign rather than prescribed by them as Bentham had earlier recognised. ${ }^{26}$ However, as we shall see, Salmond the judge stayed firmly within legal orthodoxy when it came to deciding cases.

Salmond's views of the State as a corporation are based on the traditional English doctrine which is relatively underdeveloped. ${ }^{27}$ The community of the realm is an organised society but it has no personality. The reason is that "[t]he real personality of the King who is the Head of the State has

21 Ibid.

22 Salmond Jurisprudence, above n 2, 343.

23 Meridian Global Funds Asia Ltd v Securities Commission [1995] 2 AC 500. See JH Farrar Corporate Governance: Theories, Principles and Practice (2 ed, Oxford University Press, Melbourne, 2004) ch 5.

24 Teubner "Enterprise Corporatism", above n 12, 56.

25 See Gunter Teubner (ed) Autopoietic Law: A New Approach to Law and Society (Walter de Grayter, Berlin, 1988); Gunter Teubner and Alberto Febbrajo (eds) State, Law and Economy as Autopoietic Systems: Regulation and Autonomy in a New Perspective (European Yearbook in the Sociology of Law, Giuffre, Milan, 1992). Compare Salmond Jurisprudence, above n 2, 344-345.

26 Jeremy Bentham A Comment on the Commentaries and A Fragment on Government (JH Burns and HLA Hart eds, Athlone Press, London, 1977). See also the interesting article by P Joseph "The Crown as a Legal Concept" [1993] NZLJ 126, 179.

27 Salmond Jurisprudence, above n 2, 351 and following. See also W Blackstone's Commentaries on the Laws of England vol 1, chap III and Burns and Hart, ibid, 425 and following; Sir Frederick Pollock First Book of Jurisprudence for Students of the Common Law (6 ed, Macmillian, London, 1929) 121-2; P Joseph Constitutional and Administrative Law in New Zealand (2 ed, Thomson Brookers, Wellington, 2001) ch 16, especially 16.3.3; Hazeltine, Lapsey and Winfield, above n 17, II "The Crown as Corporation" 104. See too HLA Hart The Concept of Law (2 ed, Oxford University Press, Oxford, 1994) 221 and following. 
rendered superfluous any attribution of fictitious personality to the State itself." ${ }^{28}$ However, the King himself is, in law, no mere mortal man. Salmond said he has dual capacity as a natural person and a corporation sole. He referred to the development of the concept of the Crown to refer to the King in the latter capacity. ${ }^{29}$ Salmond saw difficulties in the concepts of the Empire and Commonwealth. The King or the Crown represents not merely the Empire as a whole but each of its parts and the result is a failure of the law to give adequate recognition to and expression of the distinct existence of these parts. ${ }^{30}$ The solution was for the law to recognise the different personality in him in respect of each of the competent parts. ${ }^{31}$ It was, in fact, views of this kind that got Salmond into trouble with Sir Robert Borden, the Canadian representative, at the Washington Conference in $1921 .{ }^{32}$ It took Sir Maurice Hankey, the British Cabinet Secretary, and all his skills to deal with Borden's resentment of a reduction of Canada's international status. ${ }^{33}$ Salmond characteristically sought refuge in legal fiction and analogy. He said: "[b]y the special and peculiar organisation of that body [The League of Nations] self-governing colonies are admitted in their own right as if they were independent states". 34

It is interesting to compare Salmond's views with those of Max Weber which appeared about the time as Salmond's $7^{\text {th }}$ edition but which he does not appear to have seen. ${ }^{35}$ Weber's views are usefully set out in Max Weber on Law and Economy and Society, edited and annotated by Max Rheinstein. In the discussion on forms of creation of rights Weber deals with associational contracts. ${ }^{36}$ He sets out a useful historical survey of the evolution of juristic personality citing Gierke and Maitland. ${ }^{37} \mathrm{He}$ emphasises that the concept of the juristic person from a legal standpoint is a tautology since the very concept of person is necessarily the juristic one. ${ }^{38}$ The determination of legal personality is just as artificial as the legal definition of "thing". That is, it is decided

28 Salmond, ibid, 352.

29 Ibid, 353. Compare Maitland, ibid, 116 who described this as "a suppressed or partially recognized corporation aggregate." See also Adams v Naylor [1946] AC 543, 555 (HL) Lord Uthwatt; Town Investments Ltd v Department of the Environment [1978] AC 359, 400 (HL) Lord Simon.

30 Salmond, ibid, 354

31 Ibid, 355.

32 Frame, above n 2, 207-208.

33 Ibid, 208.

34 Ibid.

35 First published as Max Weber Wirtschaft und Gesellschaft (JCB Mohr, Tübingen, Germany, 1922).

36 Max Rheinstein (ed) Max Weber on Law and Economy and Society (Simon and Schuster, New York, 1954) 154.

37 Ibid, 154 and following.

38 Ibid, 156. 
exclusively in accordance with selected juristic criteria. ${ }^{39}$ "The most rational actualisation of the idea of legal personality consists in the complete separation of the legal spheres of the members from the separately constituted legal sphere of the organisation." 40 While certain persons designated according to rules are regarded from the legal point of view as alone authorised to assume obligations and acquire rights for the organisation, the legal relations thus created do not at all affect the members and their property but are imputed to a separate and distinct body of assets. ${ }^{41}$ These views are similar to Teubner's autopioetic system described above.

Weber then goes on to consider the various forms of legal personality in European laws. He distinguishes between three forms of organisation - endowment, institution and corporation - basing himself on Gierke. ${ }^{42}$ Salmond had followed a similar analysis relying on the same source. ${ }^{43}$

Weber considered the institution of the State and whether this should be treated as a juristic person of private law. ${ }^{44}$ He analysed the position in Roman law and in Europe in the Middle Ages, drawing comparisons with England. He argued that the rational concept of the corporation in Roman law was a product of the imperial period, quite particularly the law of municipal corporations. ${ }^{45} \mathrm{He}$ later discussed the evolution of voluntary associations such as fraternities in Roman law, mediaeval Europe and China. He argued that mediaeval European law was influenced by Germanic forms of sodality, canon law and Roman law. ${ }^{46}$ He noted that in English law the sodality as defined by Gierke did not exist after the Norman Conquest and no concept of corporation of the continental type was developed until modern times. In this he relied on Maitland's introduction to Gierke's Political Theories of the Middle Age. ${ }^{47}$ The reason for the difference in England was the development of indigenous ideas of the corporation sole and the trust. ${ }^{48}$ The result then was something of a paradox. Neither public nor private corporations could be established in any way other than that of a special grant which would only be given for a limited purpose. ${ }^{49}$ Other forms of

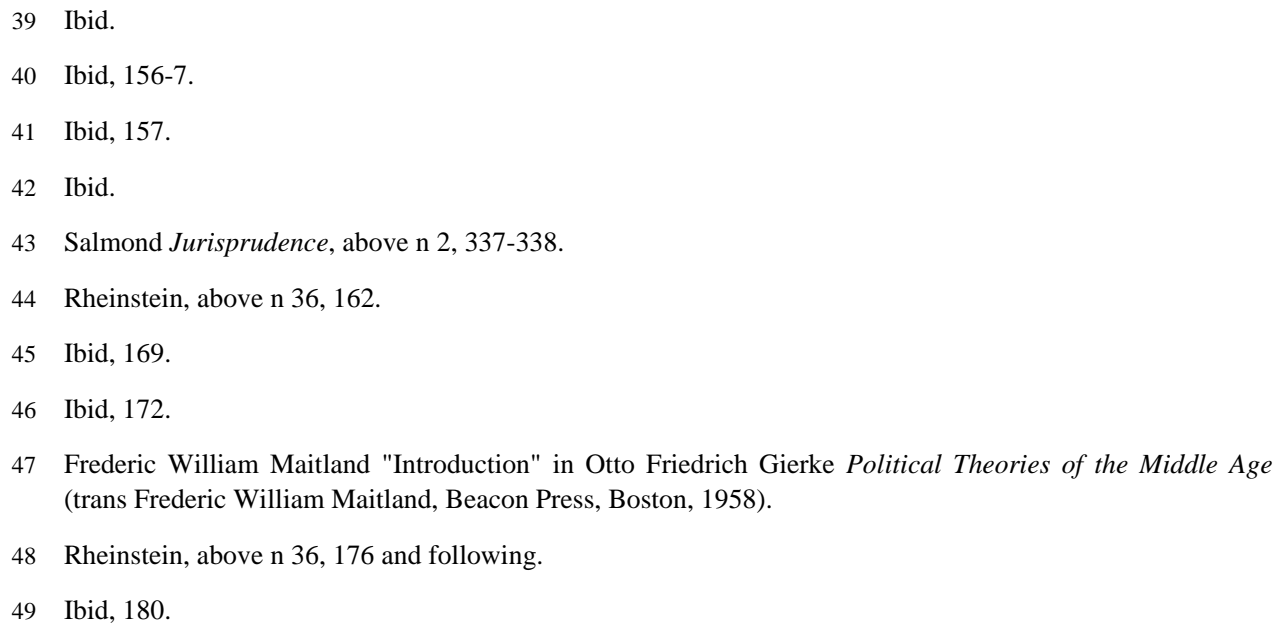


voluntary organisation had to seek refuge in the trust or have a distinctly anomalous existence such as the Inns of Court. ${ }^{50}$

It can be seen from the above that Weber's and Salmond's ideas are similar but Weber is richer in historical and comparative detail. The position with regard to corporations changed in the nineteenth century with the adoption of a more laissez faire approach to incorporation. ${ }^{51}$

\section{SALMOND'S JUDICIAL VIEWS}

The earliest corporate case which Salmond decided was Boyd v Onehunga Borough (No 2). ${ }^{52}$ This was a case involving the validity of a bylaw. Salmond J held that, although the Council might possess the power to make bylaws, if it exercised it in an unreasonable and oppressive manner in the distribution of proprietary rights without adequate and immediate action, the bylaw might be held to be invalid as unreasonable. Citing Lord Russell in Kruse $v$ Johnson ${ }^{53}$ he held that bylaws are invalid if they are manifestly unjust or if they involve such oppressive and gratuitous unfairness with the rights of those subject to them as could find no justification in the minds of reasonable men. It is noteworthy that this test is very similar to the old test for alteration of articles of association. In a later case, Takapuna Borough Council v Napier, ${ }^{54}$ the Court of Appeal was faced with another bylaw case and held that whether or not a bylaw was unreasonable was a question of fact and on the evidence the bylaw in question was unreasonable and oppressive. During the course of argument Salmond $\mathrm{J}$ asked if a bylaw is, in fact, unreasonable, is the Court bound to amend or can it not quash the bylaw altogether? ${ }^{55}$ Counsel responded that the Court should only quash a bylaw if it was egregiously unreasonable. Salmond J later asked might a bylaw be unreasonable as oppressing a dissentient minority? ${ }^{56}$ Counsel responded that no-one had protested against this bylaw. In fact, the point raised by Salmond is an interesting one which has never been decided.

50 See Black Book of Lincoln's Inn, vol II, 333 ann 1635, cited in Hazeltine and others, above n 17, xxxiii. Bishop Montague drew attention to the unincorporated nature of Lincoln's Inn. See also Sir Gerald Hurst KC A Short History of Lincoln's Inn (Constable, London, 1946) 4. "The growth of the Inns has been organic. They have no charter, no statutory privileges and so they have passed lightly through civil wars and social revolutions."

51 See Bouverie Speech on Second Reading of the Limited Liability Bill in the House of Commons (June 1855) 139 Hansard 310.

52 Boyd v Onehunga Borough (No 2) [1920] NZLR 718 (SC).

53 Kruse v Johnson [1892] 2 QB 9199 (HL).

54 Takapuna Borough Council v Napier [1922] NZLR 141 (CA).

55 Ibid, 142 Salmond J.

56 Ibid, 143 Salmond J. 
In New Zealand Farmers' Fertiliser Co Ltd v Pilbrow ${ }^{57}$ Salmond J held that a notice signed by the secretary of a company to pay a call at the company's registered office on or before a specified date was a sufficient notice of the time and place of payment. He also held that whether any evidence was produced as to the formal content of a resolution referred to in a notice it must be presumed that the resolution conformed to the terms of the notice. He distinguished the New South Wales case of Sydney Provincial Land and Building Company $v$ Le Warne ${ }^{58}$ which construed similar articles to require the nomination of some individual person or persons to receive the call. Salmond J, applying orthodox corporate theory, thought that it was sufficient to specify a body corporate.

In Re RO Clark $L t d^{59}$ the petitioning company desired to reduce its capital by cancelling shares and issuing debentures. Salmond $\mathrm{J}$ held that the proposed issue of debentures was so large as to increase the liabilities of the company and make it insolvent. He held that such a proposal was not a proper one for the sanctioning of the Court. The decision was consistent with English authority on maintenance of capital.

In JJ Craig Ltd v EA Craig and HR Craig ${ }^{60}$ the plaintiff sought an injunction restraining the defendants from carrying on a business in partnership in the name of "The Craig Transport Company" and from registering a company under the name of "The Craig Transport Company Ltd". Salmond $\mathrm{J}$ held on the facts that there was a real likelihood of confusion. He held that an incorporated company was entitled to receive the same protection in a passing off action for an established nickname as for its authorised statutory name.

Two of the most interesting corporate cases involved cooperative dairy companies. The first is MacDonald v Normanby Cooperative Dairy Factory Co Ltd, ${ }^{61}$ where Salmond J was a member of the Full Court. In this case, in an action for debt by the appellant against the respondent company, the company counter-claimed in respect of a sum alleged to be due by the appellant as calls on shares held by him in the company. The appellant contended that the shares in question had never been validly allotted to him. The Court held, Reed J dissenting, that the article in question was not one that could be amended so as to force additional shares upon a dissenting member. Salmond $\mathrm{J}^{62}$ in his judgment analysed the nature of the relationship between the contract constituted by the articles of association and an extrinsic contract. He held that a contract to justify the issue and

57 New Zealand Farmers' Fertiliser Co Ltd v Pilbrow [1920] NZLR 832 (SC).

Sydney Provincial Land and Building Company v Le Warne (1892) 13 NSWLR 238.

9 Re RO Clark Ltd [1921] NZLR 533 (SC).

JJ Craig Ltd v EA Craig and HR Craig [1922] NZLR 199 (SC).

61 MacDonald v Normanby Cooperative Dairy Factory Co Ltd [1923] NZLR 122 (SC, Full Court).

62 Ibid, 138 Salmond J. 
allotment of shares must be a real contract, not a constructive and fictitious contract. The company's contention, though ingenious, involved a logical fallacy. Before the regulation included in the articles can operate as a constructive contract under the Act it must first of all be valid as a regulation. But since the right of the company to issue shares must be constituted by a contract between the company and the shareholders such a right and obligation cannot be constituted by a regulation instead of a contract. A regulation which purports to create such a right and impose such an obligation is inoperative as a regulation and cannot, therefore, possess statutory force. Salmond J's analysis is much more lucid than that contained in the other judgments. Similar points were raised in Shalfoon $v$ Cheddar Valley Cooperative Diary Company Ltd, ${ }^{63}$ where Salmond J was a member of the Court of Appeal. In this case the respondent company had an article that provided that every shareholder should supply the company with the whole of the milk or cream produced on his farm until the share capital of each member was fully paid up. The appellant failed to supply milk in pursuance of the article and the company sued for liquided damages. The Court of Appeal held that the article in question was invalid as being an unreasonable restraint on trade and Salmond $\mathrm{J}$ held that a company cannot by its articles, whether original or amended, impose upon its members any pecuniary obligation over and above their statutory obligation to pay the amount of their shares. In the course of argument his Honour had asked probing questions and in his judgment he adopted a lucid analysis of the relationship between articles and extrinsic contracts. He made the following distinctions between an actual contract and the deemed contract constituted by the articles. ${ }^{64}$ First, an extrinsic contract cannot be altered except by the mutual consent of the parties, whereas an article can be amended by the legislative authority. Secondly, a contract is personal and binds only the party who made it and its executors and administrators, whereas an article binds the owners of the shares for the time being and passes with the shares.

It is possible for a person, on accepting shares, to bind himself by an actual contract expressed or implied to accept at the same time the burden of collateral and accessory obligations. ${ }^{65}$ Whether it is expressed or implied such a contract must be proved and is not sufficiently established simply by its presence in the articles of association. This analysis, which was valuable in connection with articles of association, is now of less significance with the disappearance from the Companies Act 1993 of the deemed contract provision. The latter was a carry-over from deed of settlement companies to articles of association and disappeared with the abandonment of that model for a statutory scheme of rights. ${ }^{66}$

63 Shalfoon v Cheddar Valley Cooperative Diary Company Ltd [1924] NZLR 561 (CA).

64 Ibid, 580 Salmond J.

65 Ibid.

66 New Zealand Law Commission Company Law Reform and Restatement (NZLC R 9, Wellington, 1989) para 81. 
It can be seen from the above that Salmond $\mathrm{J}$ had a confident grasp of company law and his decided cases were consistent with his theory. At the same time he was a liberal and pragmatic decision-maker and never allowed theory to run away with fact or settled law. He did not forget that the claims of logic must give way to established practice and familiar usage, and the accidents of historical development must often be allowed to withstand the rules of scientific order. ${ }^{67}$ The lucidity of his judgments on corporate matters compares favourably with those of his contemporary judicial colleagues. It is interesting that judgments at this time in all Commonwealth jurisdictions were relatively brief. This was, no doubt, due to the fact that they were mainly written out by the judges themselves. The modern tendency of using word processors seems to have led to prolixity.

It is a pity that Salmond's premature demise in 1924 robbed us of further development of his views. It is unlikely that he would have agreed with Maitland in the humorous choice of an epitaph "Hic jacet persona ficta". Here lies a fictitious person. ${ }^{68}$

67 Pollock, above n 5, 431. Salmond was not the "dull dog" castigated by Sir Samuel Way. See Frame, above n $2,57$.

68 See Salmond Jurisprudence, above n 2, 332: "Dead men are no longer persons in the eye of the law". On Maitland see CHS Fifoot Frederic William Maitland - A Life (Harvard University Press, Cambridge (Mass), 1971) 239; AL Smith Frederic William Maitland: Two Lectures and a Bibliography (Clarendon Press, Oxford, 1908) 54-58. In fact Salmond's grave in the Karori Cemetery has the sterner inscription "To labour is the fruit of success": see Frame, ibid, 241. 